\title{
The Influence of Creativity and Ability Effort towards the Successful Efforts of Fashion Designer
}

\author{
Ratna Suhartini ${ }^{1}$,Munoto ${ }^{2}$, Ekohariadi ${ }^{3}$ \\ Home Economics Department1 \\ Electrical EngineeringDepartment2 \\ Informatics EngineeringDepartment3 \\ Universitas Negeri Surabaya \\ Surabaya, Indonesia \\ ratnasuhartini@unesa.ac.id
}

\begin{abstract}
In running a business in the field of fashion, it takes creativity and ability effort. This research aims to know the influence of creativity against the success of the effort, influence the ability of the effort towards the success of the effort, influence creativity against the success of the effort. The population in the study is a Fashion Designer. The sample is a Fashion Designer as many as 30 people. Data collection techniques using question form. Data analysis using Path analysis. The results of the research showed there is the influence of the creativity against the capabilities of the business, there is the influence of the ability effort towards the success of the effort, there are influences creativity against the success of the effort.
\end{abstract}

Keywords - ability effort, creativity, successful effort fashion designer

\section{INTRODUCTION}

Fashion is one of the important industries in the world that contributed significantly to the global economy. According to Euro monitor International, a market 2014 year clothing and shoes reached 1.7 trillion us dollars, and projected to grow to 2.2 trillion u s. dollars in 2019. Indonesia could become one of the fashion Center of the world in 2025. The desire rolling since 2012 is no reason. The first reason, is the potential of the economy. Triawan Munaf, Head of the Agency's Creative Economy mentions, fashion is the largest subsector in the creative economy, capable of contributing 31 percent of earnings in the sector. The second reason, the creativity of the designers Indonesia votes able to compete at the forefront of the global fashion industry. . The Ministry of industry through the Directorate General of small and medium Industries Wibawaningsih claimed the current industrial craft and fashion Indonesia ranked-36 of 138 countries. This position goes up at 41 in 2016. [1] This point has arranged 35 industrial cluster development roadmap of priorities, including the fashion industry

Most of the companies there are strong influences from fashion designers to manage the process. Designers in general have significant freedom to experiment [2]. Innovative cognitive Style is related directly and indirectly through selfefficacy and success Design Designer and a successful businessman. Exclusivity can be created through exploiting consumer demand for uniqueness, registering consumers into the process of production and promotion and manipulate virtual physical spaces. [3] the path towards success required a balance between exploitation and exploration of enterprise fashion design especially if are at an early stage, [4] the influence of personality, style, influences the position of the business [5] Consumer confidence about ethical fashion, based on the perception of the company's reputation in the fashion industry, affecting business in social support. [6] Interesting urban people are creative people, entrepreneurs fashion design considering urban facilities become more important. [7] Three essential components for the success of the fashion retailer that is a coherent international brand management, distribution, marketing, image of an effective relationship. [8] High brand, commitment and engagement in interacting with the fashion brand, social interaction associated with the consumer. [9] Fashion innovations have a significant impact on the attitude of the luxury fashion goods purchases among Chinese consumers. [10] creative thinking style has an impact on the success of the effort.

This research examines the creativity of fashion designers. Creativity in the field of fashion that can support the ability of businesses and the success of efforts in the field of fashion. The purpose of this research is to know whether there was influence creativity ability against the effort, influence the ability of the effort towards the success of the effort, creativity and influence toward the success of the effort.

\section{METHOD}

The research is to analyze the influence of creativity against the success of the efforts of fashion designer. The population in this research is a fashion designer. The research sample is a fashion designer as many as 30 people. Creativity is meant in this research is the ability to develop new ideas and new ways of ways in problem solving and finding opportunities, ability effort is the ability to manage, fashion designer produced works, and analyzing the market. While success is the results obtained include trust, the result of production and sales. The type of the data in the research is primary data, i.e. data directly collected by the researchers obtained from charging the now by the respondents, about creativity of fashion designers. Data obtained in this study were collected from a data source, using 
the likert scale using question form, with the rank scale 1,2,3, 4 .5 . 6 . Before use test the validity of the study instruments and reliability. Engineering calculation of the validity and reliability of using SPSS. Hypothesis testing using path analysis.

\section{A. Validity test}

The validity of this aims to test the extent of precision and accuracy of a measuring instrument in the functions. This testing is done by way of correlating between score items with a score total score after the variable total is reduced by the indicator. High correlation coefficient shows the alignment of the functions of the item with the research as a whole. The data are tested as many as 40 of the respondents using SPSS 20. "States that when the correlation coefficient is positive and greater than the corresponding indicators then 0.3 declared valid."

Items in question is said to be valid because of the creativity of the variable the value of the coefficient of correlation between the item and the item total $>0.3$ Thus only the stated question item 46 is valid and can be done in the next test. While the invalid item 5 was dismissed or not analyzed at the next stage.

The items in question variables business success is said to be valid because the value of the coefficient of correlation between the item and the item total $>0.3$. Thus the whole question of the success of business items are capable of measuring the success of business variables. On the basis of the whole eligible item validity and will be retained in the scale and used in subsequent analysis.

The items in question variables business capabilities are said to be valid because the value of the coefficient of correlation between the item and the item total $>0.3$. Thus the whole item a question of the ability of businesses capable of measuring the ability of variable business. On the basis of the whole eligible item validity and will be retained in the scale and used in subsequent analysis.

\section{B. Reliability test}

Reliability test is used to find out the reliability (consistency) of instruments (instruments of measure) in the form of a detailed questionnaire in a study using the dwarf Cronbach's Alpha, i.e. calculating the coefficient alpha. Reliability of the instrument measured by correlating the scores each grain of questions on each variable. The value of reliability is a combination of the correlation score-score.

TABLE I. TEST RELIABILITY OF RESEARCH

\begin{tabular}{|c|c|c|}
\hline Variables & Cronbach's Alpha & N of Items \\
\hline Creativity & 0.956 & 51 \\
\hline The success of the business & 0.902 & 17 \\
\hline Ability of business & 0.872 & 15 \\
\hline
\end{tabular}

The calculation result shows the value of Cronbach alpha have values greater than 0.6 so that all variables are declared and have a good reliability.

\section{RESULT AND DISCUSSION}

The hypothesis is a provisional answer to the allegations regarding something problems that still need to be tested empirically, to find out whether the alleged it was acceptable or not. This will be tested in the study is influences creativity against the ability of businesses, business ability against influence the success of the efforts and influence of creativity against the success of the effort. Pay attention to the characteristics that will be put to the test statistic used is the analysis of path or path analysis. Steps of the analysis are as follows.

\section{A. Path Coefficient}

\section{PATH DIAGRAM}

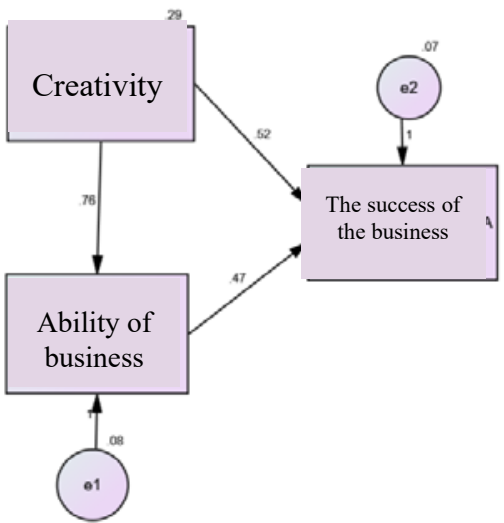

Fig. 1. The Results Of The Testing Path Analysis

The following is a table of results of testing path analysis based on the value of the coefficient of the line:

TABLE II. COEFFICIENT OF INFLUENCE VARIABLE LINE

\begin{tabular}{|l|l|l|l|}
\hline \multicolumn{3}{|c|}{ Variables } & \multicolumn{1}{|c|}{$\begin{array}{c}\text { Standardized } \\
\text { coefisient Value }\end{array}$} \\
\hline Ability Of Business & $<---$ & Creativity & 0.821 \\
\hline $\begin{array}{l}\text { The Success Of The } \\
\text { Business }\end{array}$ & $<---$ & Creativity & 0.500 \\
\hline $\begin{array}{l}\text { The Success Of The } \\
\text { Business }\end{array}$ & $<---$ & Ability Of Business & 0.418 \\
\hline
\end{tabular}

From the above table, then note that:

- If the variable creativity changing it will cause changes business capabilities . A positive sign indicates a change of direction i.e. If a variable of creativity increases then the ability of businesses will increase, and vice versa when the variable of creativity decreased then the ability of business will also be decreased by the value of the coefficient of the line 0.821 .

- If the variable creativity changing it will cause changes to the success of the effort. A positive sign indicates a change of direction i.e. If a variable of creativity increases then the success of the effort will increase, and vice versa when the variable of creativity decreased then the success of the effort will also be decreased by the value line coefficient of 0.500 . 
- If the variable business capabilities changing it will cause changes to the success of the effort. A positive sign indicates the direction of change that is if the variable business capabilities increased then the success of the effort will increase, and vice versa when the variable capability effort decreased then the success of the effort will also be decreased by the value line coefficient of 0.481 .

Based on the value of the coefficient of path analysis can be aware that the value of the coefficient of the line on the line creativity against business capabilities.

\section{B. Coefficient Of Determination}

Determination of coefficient is a coefficient that indicates the magnitude of the influence of exogenous variable contributions or endogenous and endogenous variables against endogenous variables. Following are the results of a test that showed the value of the coefficient of determination:

TABLE III. COEFFICIENT OF DETERMINATION VALUE

\begin{tabular}{|l|l|}
\hline \multicolumn{1}{|c|}{ Variables } & \multicolumn{1}{|c|}{$\mathbf{R}^{2}$} \\
\hline Creativity $\rightarrow$ Ability Of Business & 0.674 \\
\hline $\begin{array}{l}\text { Creativity And Ability Of Business } \rightarrow \text { The Success Of The } \\
\text { Business }\end{array}$ & 0.767 \\
\hline
\end{tabular}

The following is an explanation of the table above: 1. The magnitude of the change business capabilities caused by the presence of creativity awas $67.4 \%$. In other words influence creativity against the ability of the effort is $67,4 \%$. 2. The magnitude of the change the success of the business caused by creativity and the ability of the business ais $76,7 \%$. In other words, the influence of the creativity and ability of effort towards the success of the venture is $76,7 \%$.

\section{Proving The Hypothesis}

There is not a Parameter influence partially knowable on the basis of the value of the CR (Critical Ratios). To determine whether or not there is the influence of endogenous variables exogenous against endogenous and endogenous, used against the provisions of the notice of the significant level of $\mathrm{a}=$ 0.05 . If the value of $\leq 0.05$ significance then there is the influence of endogenous or exogenous variables against endogenous against endogenous. And vice versa if value $>0.05$ significance then there is no influence of endogenous or exogenous variables against endogenous against endogenous. Following is the result of the hypothesis.

TABLE IV. RESULTS OF HYPOTHESIS TESTING DIRECT EFFECT

\begin{tabular}{|l|l|l|l|l|}
\hline \multicolumn{3}{|c|}{ Variables } & \multicolumn{1}{c|}{$\begin{array}{c}\text { CR } \\
\text { count }\end{array}$} & $\begin{array}{c}\text { Rate The } \\
\text { Sig. }\end{array}$ \\
\hline $\begin{array}{l}\text { Business } \\
\text { Capabilities }\end{array}$ & $<---$ & Creativity & 8.972 & 0,000 \\
\hline $\begin{array}{l}\text { The Success Of } \\
\text { The Business }\end{array}$ & $<---$ & Creativity & 3.691 & 0,000 \\
\hline $\begin{array}{l}\text { The Success Of } \\
\text { The Business }\end{array}$ & $<---$ & $\begin{array}{l}\text { Ability Of } \\
\text { Business }\end{array}$ & 3.086 & 0,002 \\
\hline
\end{tabular}

a) The first hypothesis: There is an influence of creativity on business ability

Testing by using the value of CR earned value 8,972 with a level of significance of 0.000 . The value of this significance less than 0.05 . So the first hypothesis stating There the influence creativity against the ability of the undertakings accepted.

b) The second hypothesis: There is an effect of business ability on business success

Testing by using the value of CR earned value 3,691 with a level of significance of 0,000 The value of this significance smaller of 0.05 . So the first hypothesis stating There the influence of the ability of the crusade against the success of business accepted.

c) Testing The third hypothesis: There is an influence of creativity on business success

Testing by using the value of CR earned value 3,086 with a level of significance of 0.002 . The value of the significance of this is more minor than 0.05 . So the third hypothesis stating ada influence creativity against the success of business accepted.

Influence on the success of the business creativity fashion designer. Creativity is correlated with the success of the effort. A positive correlation values shows that the higher the creativity of business success then the higher, and vice versa. The corporate world was filled with uncertainty would result. Different ideas are not necessarily going to respond positively by consumers, while better ideas according to fashion designer is not necessarily better for consumers. [32] If fashion designer strategize troubleshooting, doing activity, and the decision is accompanied by an attitude of optimism, it will create a fashion designer can handle the uncertainty of the results will focus on things to done for the sake of achieving the objectives. Fashion Designer will apply the results of thinking about trouble solving strategy and it made good with creative ways that the results will be good. On the other hand, optimism that he can overcome the problems and uncertainties and accompanied by creative thinking can overcome obstacles because the real action is accompanied by the results of creative thinking style. ..

Creative thinking is the antecedent of behavior that will be exhibited by individuals. Trend Fashion designers to think creatively will be manifesting when Fashion designers gather information, think, create, and decided to confront the problems of creative solutions in the business. Creative thinking will also be visible from the products in the form of ideas and solutions that tend to adaptive or innovative. Those ideas could be the idea in making product design, fashion, business place decorating modification, marketing methods, or methods of creative materials faster with minimal materials production costs. In the end the behavior that produces the product of this creative will be able to impact on the success of the effort.

Creativity affects the success of fashion designer business. Creativity correlates with business success. A positive correlation value indicates that the higher the creativity the higher the business success, and vice versa. Johnson, the 
business world is filled with uncertainty about results. Different ideas will not necessarily be responded positively by consumers, while a better idea by fashion designer is not necessarily better for consumers. If Fashion designers develop problem-solving, creativity, and decision-making strategies along with optimism attitude, it will make fashion designers able to handle the uncertainty of the outcome with a focus on what needs to be done to achieve the goal. [33]. Fashion Designer will apply the results the idea of a problem-solving strategy that he creates well in creative ways that the outcome will be good on the other hand, optimism that he can solve problems and uncertainty and accompanied by creative thinking can overcome obstacles because accompanied by concrete actions of the creative thinking style.

Creative thinking is an antecedent of behaviour to be demonstrated by individuals. The tendency Fashion designers to think creatively will manifest when Fashion designers gather information, think about, create, and decide creative solutions to deal with problems in business. Creative thinking will also be seen from products of ideas and solutions that tend to be adaptive or innovative. The idea could be an idea in making designs, fashion products, decorating the place of business, marketing methods, or methods of material creation faster with materials that cost less production. Ultimately the behaviour that produces this creative product will have an impact on the success of the business.

\section{CONCLUSION}

Based on the results of the study and discussion of the choices about the influence of the creativity and ability of the crusade against the success of the effort can be drawn the following conclusions.

- There is influence creativity ability against businesses with a level of significance of 0.000 . The value of this significance less than 0.05 . So the first hypothesis stating There the influence creativity against the ability of the undertakings accepted.

- There is the influence of the ability of the crusade against the success of the venture with significance level 0,000 this significance Value smaller than 0.05 . So the first hypothesis stating There the influence of the ability of the crusade against the success of business accepted

- there is the influence of creativity against the success of the venture with a level of significance of 0.002 . The value of the significance of this is more minor than 0.05 . So the third hypothesis stating a influence creativity against the success of business accepted

\section{REFERENCES}

[1] Gati, "Industri Kriya dan Fashion Indonesia ada di Urutan Ke-36 Dunia," bisnis.tempo.co/read/1033000, 2017

[2] Bandinelli, Romeo, "New Product Development in Fashion Industry: An Empirical Investigation Of Italian Firm," International Journal of Engineering Business Management, Vol.5, July 2013.

[3] Hrac, J. Brian, "Standing Out In The Crowd: The Rise Of ExcluxivityBased Strategies to Compete in the Contemporary Marketplace for
Music and Fashion," International Journal of Environment and Palnning A 2013, Volume 45, pp 1144-1161, August 2013.

[4] Jacobs, Sofie, "Unraveling Belgian Fashion Designers High Perceived Success: A Set-Theoretic Approach," International Journal of Business Research XXX, July 2015.

[5] Mccoll, Julie, It's Vintage Darling an Exploration of Vintage Fashion Retailing, International Journal of the Textile Institute, Volume 104, pp 140-150, Jun 2013.

[6] Shen, Bin, Wang Yulan, "The Impact of Ethical Fashion on Consumer Purchase Behavior," International Journal of Marketing and Management, Volume 16, pp 235-245, 2012.

[7] Wenting, Rik, " Economic Success of Dutch Fashion Entrepreneurs Urban and Agglomeration Economic?" International Journal of Urban Studies Journal Foundation, Mei 2011

[8] Wigley, Rik, “ Current Research Development Papers. The Operationalization of International Fashion Retailer Success," International Journal of Fashion Retailer Success, Volume 11, February 2007

[9] Wolny and Julia," Analysis of Fashion Consumers" Motives to Eangage in Electronic Word-of-mouth Communication Social Media Platform,' International Journal of Marketing Management, Volume 29, pp5-6, 2013

[10] Zhang, Bopeng, "Luxury Fashion Consumption in China: Factors Affecting Attitute and Purchase Intent," International Journal of Retailing and Consumer Services, October 2013

[11] G, Frings, S, " Fashion: from Concept to Consumer $3^{\text {rd }}$, Edition, Prentice Hall, 1991

[12] Fatma," The Creative Role of Source of Inspiration in Clothing Design," International Journal of Clothing Science and Technology, Volume 18 pp 278-293, 2006

[13] R. Cooper Press M, The Design Agenda: A Guide to Successful Design management," Wiley and Sons, England,1995

[14] H, Carr \& Pomeroy,J, Fashion Design and Product Development, Oxford, Blackwell Scientific Publication,1992

[15] N, Potter, "What is Designer; Things, Places, Messages, $3{ }^{\text {rded, Hyphen }}$ Press London, 1989

[16] S, Atkinson, "Design and Marketing Fashion Product ini Easy (ed) Marketing," pp 107-137, Oxford, Balckwell Publication, 1995

[17] Suryana, “ Kewirausahaan,” Salemba Empat, Jakarta, 2003

[18] Buchari, Alma, " Manajemen Pemasaran dan Pemasaran Jasa, Alfabeta Kotler, Philip, 2008

[19] Mete, Fatma, " The Creative Role Sources of Inspiration in Clothing Design," International Journal of Clothing sciences and Technology, Volume 18, 2006

[20] M, Matlin, W, “ Cognition, $5^{\text {th }}$ edition," Harcourt College Publishers, Orlando, FI, USA

[21] J, Arlidge, "Future of Britain's Luxury Brand is in the Past,' http://www.just-style.com, October 2000

[22] L, Achtenhagen, Dynamics of Business Models - Strategizing, Critical Capabilities and Activities for Sustained Value Creation," International Journal of Long Range Planning, Volume 46, pp 427-442, 2013

[23] Fatma \& Genc, "Innovation Intelligence and Entrepreneurship in the Fashion Industry," International Journal of Social and Behavioral Sciences, Volume 41, pp 315-321, 2012

[24] L, Chaterine \& Wang, L, “ Dynamic Capabilities: A Review and Research Agenda," International Journal of Management Review, Volume 9, pp 31-51, 2007.

[25] Cohen \& Levintal, " Absorptive Capacity: A New Perspective on Learning and Innovation," Journal International of Administrative Science Quarterly, Volume 35, pp 128-152, 1990.

[26] B, Charavarthy, "Adaptation a Promising Metaphor for Strategic Management," Academy of management Review , Volume 7, pp 35-44, 1982

[27] Federico \& Caniato, "Dynamic Capabilities for Fashion -Luxury Supply Chain Innivation," International Journal of Retail \& Distribution Management, Volume 41, pp 940-960, July 2013. 
[28] Yan, Chen, "IT Capability and Organizational Performance: The Roles of Business Process Agility and Environmental Factors," International Journal of Information System, Volume 23, 2014.

[29] H, Kerzner, "Applied Project Management, Best Practices on Implementation," New York: John Wiley, 2000.

[30] Lim, "Criteria of Project: an Exploratory re-examination," International Journal of Project management, Volume 12, pp 243-248, 1999.

[31] G, Doug, "Strategies for Advancing Organization Innovation", International Journal of Management and Marketing, Volume 15 April 2014

[32] Johnson, M. W. (2010). "Seizing the White Space: Business Model Innovation for Growth and Renewa." Boston, Mass: Harvard Business Press
[33] Liang, C. \& Dunn, P. (2007). Triggers of the decision to launch a new venture - Is there any difference between pre-business and in-business entrepreneurs? Academy of Entrepreneurship Journal, 13(1), 79-88. 